can be seen by references to them in Celsus, Pliny, Marcellus Empiricus and Julius Modestus. In the Middle Ages a combination of folk-lore with orthodox practice is illustrated by the fact that Aetius of Amida (fourth century A.D.) recommended that after other methods had failed to remove a foreign body from the throat it should be invoked in the name of St. Blaise, the patron saint for diseases of this kind, "to come up or go down". In the eighteenth century, numerous popular terms, especially in Scotland, were given to a special form of laryngitis occurring in children, such as 'croup', 'croops', 'chock', 'stuffing' or 'rising of the lights'. As in the case of many other diseases and morbid conditions, folk-lore has only a few prophylactic measures compared with curative treatment, while its therapy can be grouped under animal remedies, plant remedies, patron saints and miscellaneous remedies.

\section{Earthquakes Registered in New Zealand}

DURING April 1943, eleven strong distant earthquakes were registered by the seismographs at Auckland, Arapuni, Christchurch, Kaimati, New Plymouth, Tuai and Wellington, New Zealand. The earthquake of April 6 registered at most of the New Zealand stations occurred at $16 \mathrm{~h} .07 \cdot 1 \mathrm{~m}$. U.T. near latitude $32^{\circ} \mathrm{S}$., longitude $70^{\circ} \mathrm{W}$., according to the U.S. Coast and Geodetic Survey. This is mid-way between Illapel and Mendoza in Chile. The earthquake also registered at College, St. Louis, Ottawa, Sitka, Georgetown and fourteen other stations sending records to Washington. The earthquake of April 9 occurred at about $8 \mathrm{~h} .48 \cdot 8 \mathrm{~m}$. U.T. from an epicentre as determined by the U.S. Coast and Geodetic Survey near latitude $19^{\circ} \mathrm{N}$., longitude $145^{\circ} \mathrm{E}$., which is in the Pacific Ocean west of Agrigan Island, one of the Marianas Islands. In this case the depth of focus was near $100 \mathrm{~km}$. Additionally, twenty-nine local earthquakes and earth tremors were recorded. Five of these shocks reached intensity $V$ on the modified Mercalli scale. The first, on April 6, was felt in the Wairoa region; the second, also on April 6, was felt near Hawkes Bay; the third, on April 7, was also felt near Hawkes Bay; the fourth, on April 15, was felt over the southern part of North Island, while the fifth, also on April 15, was felt at Manawatu and Wairarapa.

\section{Food Situation in Sweden}

According to the Anglo-Swedish Review of July, comparison of Sweden's rations with those of foreign countries seems to show that the Swedish rations are surprisingly small. Three important products, how ever, namely, milk, potatoes and other vegetables, are not rationed but can be bought in unlimited quantities. Temporary visitors to Sweden who eat their meals at restaurants may think the food situation is more favourable than it really is. In a restaurant coupons are only required for butter, bread, most of the meat products and eggs. On the other hand, for Swedish households the coupon-free meat products play a very minor part, and their price is so high that they are almost beyond the reach of most consumers.

\section{Space Heating}

For his chairman's address to the Installations Section of the Institution of Electrical Engineers, R. Grierson took the subject of "British Climate and the Space-Heating Engineer" $(J$. Inst. Elec. Eng., 90, Pt. I, No. 29; May 1943) in which the means of assessing the thermal performance of space-heating installations on a rational basis rather than on the present empirical one are indicated. The address first reviews the basic factors involved in space-heating problems, then proceeds to discuss the internal temperatures required for maintaining the desired standard of thermal comfort, external temperatures, and temperature difference and degreedays. The address is printed in abstract in the Journal, but the complete text may be referred to in the Institution Library.

\section{Utilization of Small Coals}

THe British Coal Utilisation Research Association is arranging a conference on November 10 and 11 to discuss the problems related to the utilization of small coals with particular reference to the results obtained by the users of these fuels. It is known that a great body of valuable experience on the subject exists, and it is hoped, by means of the Conference, to make this experience available to those concerned, and by discussion to direct attention to the most practical and effective methods of utilization. The Conference has the full support and approval of the Fuel Efficiency Committee. There will be three sessions: November 10, at 2.30, on utilization of small coals and slurries; November 11, at 10, on utilization of fuels of high inert content; November 11 , at 2.30, on the upgrading of fuels. Offers of papers for discussion at the Conference should be sent to the Conference Secretary, B.C.U.R.A., Rickett Street, West Brompton, London, S.W.6. The Conference will be open without charge to all interested, by tickets obtainable from the Conference Secretary. Papers will be circulated in advance and the proceed. ings confined to a discussion of the papers.

\section{Searle's "Experimental Optics"}

Dr. G. F. C. Searle writes that additional accommodation for students attending the Cavendish Laboratory, Cambridge, has been obtained in the Geological Museum, and the task of transferring the opties class to that Museum has begun. Dr. Searle's "Experimental Optics", which is required for the course contemplated, is out of print, and Dr. Searle asks former pupils to offer copies of this book which they may have retained to the Laboratory. Letters should be sent to Dr. Searle before sending the books; the Laboratory will pay $16 s$. for each copy in fair condition.

\section{Colonial Service Appointments}

THE following appointments have recently been made in the Colonial Service: J. F. G. Wheeler to be marine biologist, Mauritius; J. C. Eyre, agricultural officer, Tanganyika Territory, to be senior agricultural officer, Palestine; J. Smith, assistant conservator of forests, Nigeria, to be senior assistant conservator of forests, Nigeria; J. E. Taylor, assistant conservator of forests, Nigeria, to be senior assistant conservator of forests, Nigeria; R. C. Burgess, lands officer and senior surveyor, Sierra Leone, to be director of surveys and lands, Sierra Leone; W. Harrison, surveyor, Nigeria, to be senior surveyor, Gold Coast. 